\section{Drs. Pimentel-Santos and Branco reply}

\section{To the Editor:}

We appreciate the interest ${ }^{1}$ in our report ${ }^{2}$ in which $A N K H$ polymorphisms were not identified as major determinants of susceptibility to ankylosing spondylitis (AS) and do not influence phenotypic characteristics of AS age at disease onset or results of the Bath AS Disease Activity Index, Bath AS Functional Index, or modified Stoke Ankylosing Spondylitis Spine Score $^{2}$.

Occurrence of renal stones was not evaluated in our study of Portuguese patients with $\mathrm{AS}^{2}$. There are some data showing an increased prevalence of renal stone formation in patients with AS/spondyloarthritis $^{3,4}$. Moreover it was described that the transmembrane protein ANKH is expressed in kidney tissues such as cilia and basal body structures, as well as epithelial cells ${ }^{5}$. Considering the function of $A N K H$ as a pyrophosphate transporter and regulator of tissue calcification, a potential role in renal stone formation represents an interesting hypothesis for study. However, no association between $A N K H$ and renal stone formation was seen in the study described by Korkmaz and Sayer ${ }^{1}$; it is important to mention that that study was clearly underpowered to elicit evidence for this kind of association.

Despite weak positive associations described by some authors ${ }^{6,7}$, there is convincing evidence that the $A N K H$ gene has no significant role in $\mathrm{AS}^{2,8}$. In addition, no association was identified with this gene and AS susceptibility in large studies using high numbers of nonsynonymous $\mathrm{SNP}^{9}$ or in genome-wide association studies ${ }^{10}$.

There are several concerns regarding the studies focusing on ANKH variants: (1) methodological differences (ethnicity, case ascertainment approaches, and $A N K H$ marker variants analyzed); and (2) all of them were underpowered to detect genes with small effects consistently. Thus further studies are needed to reach definitive conclusions.

FERNANDO MANUEL PIMENTEL-SANTOS, MD, MSc, CEDOC, Faculdade de Ciências Médicas da Universidade Nova de Lisboa; I Instituto de Biotecnologia e Bioengenharia, Centro de Genómica e Biotecnologia, da Universidade de Trás-os-Montes e Alto Douro, Vila Real; Serviço de Reumatologia, Centro Hospitalar Lisboa Ocidental (CHLO), Hospital de Egas Moniz EPE, Lisbon; JAIME C. BRANCO, MD, PhD, CEDOC, Faculdade de Ciências Médicas da Universidade Nova de Lisboa; Serviço de Reumatologia, CHLO, Hospital de Egas Moniz EPE, Lisbon, Portugal. Address correspondence to Dr. Pimentel-Santos, Faculdade de Ciências Médicas, Universidade Nova de Lisboa - CEDOC, Campo Mártires da Pátria, nº130, Lisbon 1169-056 Portugal;

E-mail: pimentel.santos@gmail.com

\section{REFERENCES}

1. Korkmaz C, Sayer JA. ANKH and renal stone formation in ankylosing spondylitis. J Rheumatol 2012;39:1756.

2. Pimentel-Santos FM, Ligeiro D, Matos M, Mourão AF, de Sousa EV, Pinto P, et al. ANKH and susceptibility to and severity of ankylosing spondylitis. J Rheumatol 2012;39:131-4.

3. Canales BK, Leonard SM, Singh JA, Orzano IM, Zimmermann B, Weiland D, et al. Spondyloarthropathy: an independent risk factor for kidney stones. J Endourol 2006;20:542-6.

4. Korkmaz C, Özcan A, Akçar N. Increased frequency of ultrasonographic findings suggestive of renal stones in patients with ankylosing spondylitis. Clin Exp Rheumatol 2005;23:389-92.

5. Carr G, Moochhala SH, Eley L, Vandewalle A, Simmons NL, Sayer JA. The pyrophosphate transporter ANKH is expressed in kidney and bone cells and colocalises to the primary cilium/basal body complex. Cell Physiol Biochem 2009;24:595-604.

6. Furuichi T, Maeda K, Chou CT, Liu YF, Liu TC, Miyamoto Y, et al. Association of the MSX2 gene polymorphisms with ankylosing spondylitis in Japanese. J Hum Genet 2008;53:419-24.

7. Tsui HW, Inman RD, Paterson AD, Reveille JD, Tsui FW. ANKH variants associated with ankylosing spondylitis: Gender differences. Arthritis Res Ther 2005;7:513-25.

8. Timms AE, Zhang Y, Bradbury L, Wordsworth BP, Brown MA. Investigation of the role of ANKH in ankylosing spondylitis. Arthritis Rheum 2003;48:2898-902.

9. Wellcome Trust Case Control Consortium; Australo-Anglo-American Spondylitis Consortium (TASC), Burton PR, Clayton DG, Cardon LR, Craddock N, Deloukas P, Duncanson A, et al. Association scan of 14,500 nonsynonymous SNPs in four diseases identifies autoimmunity variants. Nat Genet 2007;39:1329-37.

10. Evans DM, Spencer CC, Pointon JJ, Su Z, Harvey D, Kochan G, et al; Spondyloarthritis Research Consortium of Canada (SPARCC), Australo-Anglo-American Spondyloarthritis Consortium (TASC); Wellcome Trust Case Control Consortium 2 (WTCCC2). Interaction between ERAP1 and HLA-B27 in ankylosing spondylitis implicates peptide handling in the mechanism for HLA-B27 in disease susceptibility. Nat Genet 2011;43:761-7.

J Rheumatol 2012;39:8; doi:10.3899/jrheum.120376 